\title{
The Crystal Structures of the Triammines of the
}

\section{Ammonium Halides}

\author{
IVAR OLOVSSON
}

\author{
Institute of Chemistry, University of Uppsala, Uppsala, Sweden
}

\begin{abstract}
The crystal structures of $\mathrm{NH}_{4} \mathrm{Cl} \cdot 3 \mathrm{NH}_{3}, \mathrm{NH}_{4} \mathrm{Br} \cdot 3 \mathrm{NH}_{3}$ and $\mathrm{NH}_{4} \mathrm{I} \cdot 3 \mathrm{NH}_{3}$ have been determined from single-crystal $\mathrm{X}$-ray data. No phase transitions were observed from the melting point down to $-140^{\circ} \mathrm{C}$. The crystals are orthorhombic with four molecules per unit cell; the space group for the chloride and bromide is $P 2_{1} 2_{1} 2_{1}$ and for the iodide $P 2_{1} n b$. The cell dimensions at $-35^{\circ} \mathrm{C}$ are for $\mathrm{NH}_{4} \mathrm{Cl} \cdot 3 \mathrm{NH}_{3}: a=8.795, b=8.68, c=8.989 \AA$; for $\mathrm{NH}_{4} \mathrm{Br} \cdot 3 \mathrm{NH}_{3}$ : $a=8.96, b=8.996, c=9.263 \AA$; for $\mathrm{NH}_{4} \mathrm{I} \cdot 3 \mathrm{NH}_{3}: a=8.32$, $b=9.91, c=9.96 \AA$. The ammonium ion is tetrahedrally surrounded by three ammonia molecules and one halide ion. The hydrogen atoms of ammonium are evidently involved in the hydrogen bonds within this group. The forces between the different groups are relatively weak but may restrict the possible rotation of the ammonia molecules about their threefold axes.
\end{abstract}

$\mathrm{T}_{\mathrm{T}}^{\mathrm{T}}$ The present investigation is the first in a series of planned structure determinations of some ammines formed with salts of the alkali metals and ammonium.

The systems $\mathrm{NH}_{4} \mathrm{X}-\mathrm{NH}_{3}(\mathrm{X}=\mathrm{F}, \mathrm{Cl}, \mathrm{Br}, \mathrm{I})$ have been studied in several earlier works and reported compounds are: $\mathrm{NH}_{4} \mathrm{~F} \cdot \mathrm{NH}_{3} ; \mathrm{NH}_{4} \mathrm{Cl} \cdot 3$ and $6 \mathrm{NH}_{3}$; $\mathrm{NH}_{4} \mathrm{Br} \cdot 1,3,4$, and $6 \mathrm{NH}_{3} ; \mathrm{NH}_{4} \mathrm{I} \cdot 1,2,3,4,5$, and $6 \mathrm{NH}_{3}$. A list of references is given in the work by Watt and McBride ${ }^{1}$. The compounds $\mathrm{NH}_{4} \mathrm{Cl} \cdot 3 \mathrm{NH}_{3}$, $\mathrm{NH}_{4} \mathrm{Br} \cdot 3 \mathrm{NH}_{3}, \mathrm{NH}_{4} \mathrm{I} \cdot 3 \mathrm{NH}_{3}$ and $\mathrm{NH}_{4} \mathrm{I} \cdot 4 \mathrm{NH}_{3}$ seem to be established with certainty in these works. The present investigation involves the determination of the crystal structures of $\mathrm{NH}_{4} \mathrm{Cl} \cdot 3 \mathrm{NH}_{3}, \mathrm{NH}_{4} \mathrm{Br} \cdot 3 \mathrm{NH}_{3}$ and $\mathrm{NH}_{4} \mathrm{I} \cdot 3 \mathrm{NH}_{3}$ from single crystal $\mathrm{X}$-ray diffraction data obtained at $-35^{\circ} \mathrm{C}$. A preliminary report of the work on these compounds has been published earlier ${ }^{2}$.

\section{EXPERIMENTAL}

The crystals were grown from [solutions of ammonia and ammonium halide sealed in glass capillaries. The capillaries were made by drawing out one end of a thinwalled glass tube (diameter about $2 \mathrm{~mm}$ ) to a diameter of 0.1 to $0.2 \mathrm{~mm}$ and a wall

Acta Chem. Scand. 14 (1960) No. 7 
thickness of 0.01 to $0.02 \mathrm{~mm}$. The ammonium halide was weighed into the capillary and carefully dried ammonia condensed over it. Reweighing, after sealing with a microflame, gave the amount of ammonia. The desired composition was easily obtained by trial and error. The melting points of the samples were in reasonable agreement with earlier published data; a sample of the chloride used for the X-ray work with a composition 3.0 moles $\mathrm{NH}_{3} /$ mole $\mathrm{NH}_{4} \mathrm{Cl}$ melted at $+10^{\circ} \mathrm{C}$ (reported values $7^{\circ}, 7.6^{\circ}, 9^{\circ}, 8^{\circ}, 0^{\circ}$ ). For $\mathrm{NH}_{4} \mathrm{Br} \cdot 3 \mathrm{NH}_{3}$ (actual composition 2.9 moles $\mathrm{NH}_{3} /$ mole $\mathrm{NH}_{4} \mathrm{Br}$ ) the melting point was $+8.5^{\circ} \mathrm{C}$ (reported $\left.6^{\circ}, 8.7^{\circ}, 13.7^{\circ}\right)$, for the iodide $\left(3.1\right.$ moles $\left.\mathrm{NH}_{3} / \mathrm{mole} \mathrm{NH}_{4} \mathrm{I}\right)-9^{\circ} \mathrm{C}$ (reported $-8^{\circ},-12^{\circ}$ ).

The X-ray photographs were taken in a special Weissenberg camera ${ }^{3}$, modified to make it even simpler to handle. It was then also possible to use an undivided film which has some obvious advantages. The single crystals were grown in the camera in the usual way by blowing a cooled stream of gas parallel to the capillary and following the growth with a polarizing microscope. The crystals apparently grow with no strongly preferred orientation with respect to the capillary as they were differently oriented in each case. In this case the cooling gas was carefully dried air, passed through copper spirals in solid carbon dioxide or liquid air. The consumption of liquid air was $0.51 / \mathrm{h}$ when working at $-140^{\circ} \mathrm{C}$. The other details are similar to those described earlier 4

Equi-inclination Weissenberg photographs were taken at $-35^{\circ} \mathrm{C}$ by use of $\mathrm{Cu}-K$ radiation; for the chloride with rotation about the $a$ and $b$ axes (layers $0-6$ and $0-8$, resp.), for the bromide about the $a$ axis (layers $0-7$ ) and for the iodide about the $a$ axis (layers $0-6$ ). In addition, exposures were taken at $-10^{\circ},-85^{\circ}$ and $-140^{\circ} \mathrm{C}$, but no changes in structure were indicated by these photographs.

A crystal grown from a sample of the composition 4.1 moles $\mathrm{NH}_{3} / \mathrm{mole} \mathrm{NH}_{4} \mathrm{Cl}$ gave the same X-ray photographs as $\mathrm{NH}_{4} \mathrm{Cl} \cdot 3 \mathrm{NH}_{3}$.

The relative intensities were estimated visually by using the multiple-film technique (five films) and comparing with an intensity scale. The intensities varied from 1 to 8000 . The data were corrected for the Lorentz and polarization effects.

\section{UNIT CELL}

The data showed the diffraction symmetry $\mathrm{mmm}$, indicating an orthorhombic unit cell. The approximate cell dimensions were first obtained from rotation and Weissenberg photographs; accurate determination with powder methods was impossible as the crystallites could not be obtained sufficiently small. A single crystal method described by Weisz, Cochran and Cole ${ }^{5}$ was therefore applied ("the $\Theta$-method"). The selected reflection was located to half a degree on the scale of rotation by Weissenberg oscillations of $\pm 2^{\circ}$. A series of exposures was then made with stationary camera and crystal, using a special collimator of $0.15 \mathrm{~mm}$ diameter. The crystal was turned $10^{\prime}$ between successive exposures and by interpolation between the estimated intensities, the crystal orientation for maximum reflection intensity could be determined to better than $\pm 5^{\prime}$. Systematic errors in the measurements were eliminated by extrapolation to $\Theta=90^{\circ}$. The errors due to eccentricity and graduation on the scale of rotation were negligible.

The method as given only determines the axes occurring in the zero layer and to obtain the dimensions of all three axes the crystal must be remounted. According to a modified method by Löfgren ${ }^{6}$, the dimension of the rotation axis is obtained directly from the higher layers without reorientation. As the reflections were relatively more diffuse in the higher layers, there was here a larger uncertainty in the determination of the crystal orientation for maximum reflection intensity. The cell dimensions obtained are: 
$\mathrm{NH}_{4} \mathrm{Cl} \cdot 3 \mathrm{NH}_{3}: a=8.795 \pm 0.002, b=8.68 \pm 0.01, c=8.989 \pm 0.002 \AA$ $\mathrm{NH}_{4} \mathrm{Br} \cdot 3 \mathrm{NH}_{3}: a=8.96 \pm 0.01, b=8.996 \pm 0.002, c=9.263 \pm 0.002 \AA$ $\mathrm{NH}_{4} \mathrm{I} \cdot 3 \mathrm{NH}_{3}: a=8.32 \pm 0.02, b=9.91 \pm 0.01, c=9.96 \pm 0.01 \AA$ $\left(t=-35^{\circ} \mathrm{C}, \lambda \mathrm{Cu}-K \alpha_{1}=1.54051 \AA, \lambda \mathrm{Cu}-\bar{K} \alpha_{2}=1.54433 \AA\right.$.)

From existing literature data, no definite conclusions can be drawn about the extent of solid solutions in these systems.

The approximate density was obtained from the volume and weight of a completely homogeneous crystal in a cylindrical capillary of uniform thickness. The volume was measured with a microscope, the weight being known from the preparation. The densities thus observed, together with those calculated with four molecules per unit cell are $\left(t=-35^{\circ} \mathrm{C}\right)$ :

$$
\begin{aligned}
& \mathrm{NH}_{4} \mathrm{Cl} \cdot 3 \mathrm{NH}_{3}: d_{\text {obs }}=1.0, d_{\text {calc }}=1.01 \mathrm{~g} \cdot \mathrm{cm}^{-3} \\
& \mathrm{NH}_{4} \mathrm{Br} \cdot 3 \mathrm{NH}_{3}: d_{\text {obs }}=1.4, d_{\text {calc }}=1.33 \\
& \mathrm{NH}_{4} \mathrm{I} \cdot 3 \mathrm{NH}_{3}: d_{\text {obs }}=1.6, d_{\text {calc }}=1.59
\end{aligned}
$$

\section{SPACE GROUP}

Systematic absences for the chloride and bromide compounds were: $(h 00),(0 k 0),(00 l)$ for $h, k$ and $l$ odd, resp. This suggests the space group $P 2_{1} 2_{1} 2_{1}\left(D_{2}^{4}\right)$, assuming that the absences are space group extinctions. The subsequent refinement of the structure in this space group gave good agreement with the data indicating that this choice is correct.

For the iodide compound the systematic absences were: $(h 0 l)$ for $h+l$ odd, $(h k 0)$ for $k$ odd. This suggests $P 2_{1} n b$ or $P m n b$ (with different choice of axes these correspond to $P n a 2_{1}$ and $P n m a$ of the International Tables ${ }^{7}$ ). As will be shown later, the structure could be refined successfully only in $P 2_{1} n b$ $\left(C_{2 v}^{9}\right)$.

In the chloride and bromide structure the atomic arrangement is about the same as in the iodide; the differences are discussed in detail later. However, it was evident from the refinements that the iodide structure could not be brought into sufficiently good agreement with the data by the use of $P 2_{1} 2_{1} 2_{1}$ (see further below). The original choice of axes was made such that all structures were oriented in the same way. The work on the chloride and bromide was finished before the space group of the iodide was established with certainty, and the original choice of axes was then maintained even though this does not correspond to the standard setting of the International Tables ${ }^{7}$ for the iodide.

The equivalent positions for $\mathrm{NH}_{4} \mathrm{Cl} \cdot 3 \mathrm{NH}_{3}$ and $\mathrm{NH}_{4} \mathrm{Br} \cdot 3 \mathrm{NH}_{3}$ in $P 2_{1} 2_{1} 2_{1}$ are: $(x, y, z) ;\left(\frac{1}{2}+x, \frac{1}{2}-y, z\right) ;\left(\frac{1}{2}-x, \bar{y}, \frac{1}{2}+z\right) ;\left(\bar{x}, \frac{1}{2}+y, \frac{1}{2}-z\right)$. For $\mathrm{NH}_{4} \mathrm{I} \cdot 3 \mathrm{NH}_{3}$ in $P 2_{1} n b:(x, y, z)$; $\left(\frac{1}{2}+x, \frac{1}{2}-y, \bar{z}\right) ;\left(\frac{1}{2}+x, \bar{y}, \frac{1}{2}+z\right) ;\left(x, \frac{1}{2}+y, \frac{1}{2}-z\right)$. The arrangement of the symmetry elements in $P 2_{1} n b$ with the chosen setting is given in Fig. 1.

\section{DETERMINATION OF THE ATOMIC COORDINATES}

The positions of the halogen atoms were obtained independently for each substance from the Harker vectors. From three-dimensional $F_{o}$ and $F_{o}-F_{c}$ syntheses based on these positions, the coordinates of the nitrogen atoms were

Acta Chem. Scand. 14 (1960) No. 7 


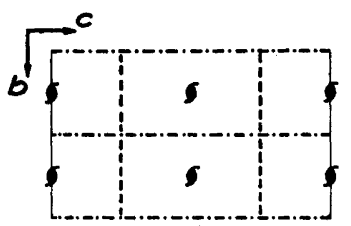

Fig. 1. The arrangement of the symmetry elements in $P 2_{1} n b$.

then determined. The analogue computer by Hägg and Laurent ${ }^{8}$ was used for the preliminary Fourier calculations. Subsequent Fourier refinements were made on the IBM 701 computer.

For the chloride and bromide compounds, the refinements gave no indication of deviation from the space group $P 2_{1} 2_{1} 2_{1}$ suggested by the systematic absences. In the iodide, there was first of all a choice between $P 2_{1} n b$ and $P m n b$. The latter space group was first tried; the general positions are eightfold and the iodine atom had to be placed in a special fourfold position on a mirror plane. From the $F_{o}-F_{c}$ syntheses based on this iodine position, quite acceptable nitrogen peaks could be found for $\mathrm{N}_{0}, \mathrm{~N}_{2}$ and $\mathrm{N}_{3}\left(\mathrm{~N}_{0}\right.$ is nitrogen in the ammonium ion; $\mathrm{N}_{1}, \mathrm{~N}_{2}$ and $\mathrm{N}_{3}$ are the nitrogen atoms in the three ammonia molecules; see further below). $\mathrm{N}_{0}$ then was in a special fourfold position and $\mathrm{N}_{2}$ and $\mathrm{N}_{3}$ together occupied a general eightfold position. Finally, the remaining $\mathrm{N}_{1}$ had to be placed in a fourfold position on a mirror plane, although the very pronounced elongation of the corresponding Fourier peak rather indicated that it should be about $0.4 \AA$ from this plane. However, the coordinates of this structure were subjected to several cycles of least-squares refinement. It appeared that the temperature factor for $\mathrm{N}_{1}$ became successively larger, while the other atoms refined rather normally. Soon the temperature factor for $\mathrm{N}_{1}$ had grown beyond all reasonable limits, thus confirming the indications from the difference synthesis that $\mathrm{N}_{1}$ should not be placed on the mirror plane. As the structure now discussed was the only one to be considered in $P m n b$ this space group had to be abandoned and $P 2_{1} n b$ was tried. Here all positions are general fourfold and $\mathrm{N}_{1}$ could be moved away from the old mirror plane. Also, $\mathrm{N}_{2}$ and $\mathrm{N}_{3}$ were of course no longer symmetry-related to each other. Apart from this, no changes were undertaken in the above structure. The subsequent least-squares refinement in $P 2_{1} n b$ now proceeded successfully.

Finally, one possibility that should be considered is that the systematic absences are not real space group extinctions and that the space group of the iodide then might be, for example, the same as for the chloride and bromide, $P 2_{1} 2_{1} 2_{1}$. The arguments against this alternative are similar to those presented above against $P m n b$. From the equivalent positions written down earlier, it is evident that if the actual space group is $P 2_{1} 2_{1} 2_{1}$, but the $x$ coordinates of $\mathrm{I}$, $\mathrm{N}_{0}$ and $\mathrm{N}_{1}$ very close to 0.50 , the coordinates for $\mathrm{N}_{2}$ are $\left(x_{2}, y_{2}, z_{2}\right)$ and for $\mathrm{N}_{3}$ very close to $\left(\bar{x}_{2}, y_{2}, z_{2}\right)$; the net result is false absences corresponding to those for $P 2_{1} n b$. However, from the difference maps, for example, it was evident that the $x$ coordinate of $\mathrm{N}_{1}$ should be about 0.45 . This is so far from 0.50 that the false space group extinctions would be easily revealed. 
The relation between the structures of $\mathrm{NH}_{4} \mathrm{Cl} \cdot 3 \mathrm{NH}_{3}$ and $\mathrm{NH}_{4} \mathrm{Br} \cdot 3 \mathrm{NH}_{3}$ on one hand, and $\mathrm{NH}_{4} \mathrm{I} \cdot 3 \mathrm{NH}_{3}$ on the other, may be described in the following way. The space groups $P 2_{1} 2_{1} 2_{1}$ and $P 2_{1} n b$ are both subgroups of $P m n b$ (full symbol $\left.P 2_{1} / m 2_{1} / n 2_{1} / b\right)$ and the two different structures represent two different distortions from that higher symmetry. The practical difference in the two distortions is that in one case the extinction rules change and in the other they do not. The hypothetical structure for $\mathrm{NH}_{4} \mathrm{I} \cdot 3 \mathrm{NH}_{3}$, discussed in the preceding paragraph, approaches the symmetry $P m n b$; if the conditions were exact, it would be the ideal structure from which the two actual ones can be considered to be derived.

The coordinates and isotropic temperature factors for the halogen and nitrogen atoms and an over-all scale factor were finally refined by least-squares methods on the IBM 650 computer. $R_{3}$, (see below), was the quantity actually minimized. The weighting factor $w$ in this expression and some other details of the program are described elsewhere ${ }^{4}$. In the iodide, the chosen space group $\left(P 2_{1} n b\right)$ is polar, but with a single heavy atom, the least-squares refinement using only diagonal matrix elements involves no special problems (cf. Ref. $\left.{ }^{9}\right)$. The scattering factors for $\mathrm{N}^{\circ}$ and $\mathrm{Cl}^{-}$were based on $f$-values published by Berghuis et al. ${ }^{10}$, for $\mathrm{Br}^{-}$and $\mathrm{I}^{-}$they were estimated from the $f$-values for $\mathrm{Br}^{\circ}$ and $\mathrm{I}^{\circ}$ published by Thomas and Umeda ${ }^{11}$. The shifts of the atoms in the final cycles were less than about one tenth of the standard deviation for the coordinate in question. The results together with the standard deviations after about 15 cycles of refinement are given in Table 1. (The $x$ coordinate of iodine was arbitrarily set equal to 0.50000 . There is no variance for this coordi-

Table 1. Atomic parameters and standard deviations.

\begin{tabular}{|c|c|c|c|}
\hline & $\mathrm{NH}_{4} \mathrm{Cl} \cdot 3 \mathrm{NH}_{3}$ & $\mathrm{NH}_{4} \mathrm{Br} \cdot 3 \mathrm{NH}_{3}$ & $\mathrm{NH}_{4} \mathrm{I} \cdot 3 \mathrm{NH}_{3}$ \\
\hline $\begin{aligned} \mathrm{N}_{0}: x & = \\
y & = \\
z & = \\
B & =\end{aligned}$ & $\begin{array}{l}0.479(9) \pm 0.001(2) \\
0.117(2) \pm 0.001(2) \\
0.280(1) \pm 0.001(1) \\
6.23 \AA^{2}\end{array}$ & $\begin{array}{l}0.484(6) \pm 0.002(1) \\
0.120(9) \pm 0.001(6) \\
0.288(4) \pm 0.001(7) \\
4.18 \AA^{2}\end{array}$ & $\begin{array}{l}0.487(9) \pm 0.006(9) \\
0.114(0) \pm 0.002(6) \\
0.298(4) \pm 0.002(4) \\
5.63 \AA^{2}\end{array}$ \\
\hline $\begin{aligned} \mathrm{N}_{1}: x & = \\
y & = \\
z & = \\
B & =\end{aligned}$ & $\begin{array}{r}0.434(3) \pm 0.001(2) \\
-0.111(0) \pm 0.001(2) \\
0.525(8) \pm 0.001(2) \\
6.73 \AA^{2}\end{array}$ & $\begin{array}{r}0.442(0) \pm 0.002(4) \\
-0.099(0) \pm 0.001(9) \\
0.521(3) \pm 0.002(0) \\
4.99 \AA^{2}\end{array}$ & $\begin{array}{r}0.448(2) \pm 0.006(1) \\
-0.097(0) \pm 0.004(5) \\
0.519(9) \pm 0.003(9) \\
7.84 \AA^{2}\end{array}$ \\
\hline $\begin{aligned} \mathrm{N}_{2}: x & = \\
y & = \\
z & = \\
B & =\end{aligned}$ & $\begin{array}{l}0.772(1) \pm 0.001(2) \\
0.266(6) \pm 0.001(2) \\
0.315(4) \pm 0.001(2) \\
6.19 \AA^{2}\end{array}$ & $\begin{array}{l}0.762(4) \pm 0.002(2) \\
0.264(6) \pm 0.002(1) \\
0.316(7) \pm 0.001(9) \\
5.43 \AA^{2}\end{array}$ & $\begin{array}{l}0.777(7) \pm 0.006(2) \\
0.290(0) \pm 0.004(6) \\
0.322(0) \pm 0.004(0) \\
8.20 \AA^{2}\end{array}$ \\
\hline $\begin{aligned} N_{s}: x & = \\
y & = \\
z & = \\
B & =\end{aligned}$ & $\begin{array}{l}0.234(7) \pm 0.001(1) \\
0.343(6) \pm 0.001(2) \\
0.312(3) \pm 0.001(1) \\
6.12 \AA^{2}\end{array}$ & $\begin{array}{l}0.239(4) \pm 0.002(2) \\
0.332(2) \pm 0.002(2) \\
0.314(2) \pm 0.002(1) \\
5.50 \AA^{2}\end{array}$ & $\begin{array}{l}0.243(7) \pm 0.005(1) \\
0.284(6) \pm 0.004(0) \\
0.323(9) \pm 0.003(6) \\
7.72 \AA^{2}\end{array}$ \\
\hline $\begin{array}{l}x= \\
y= \\
z= \\
B=\end{array}$ & $\begin{array}{r}0.4578(5) \pm 0.0003(3) \\
-0.0039(9) \pm 0.0003(9) \\
-0.0579(2) \pm 0.0003(2) \\
5.85 \AA^{2}\end{array}$ & $\begin{array}{r}0.4628(2) \pm 0.0002(3) \\
-0.0004(9) \pm 0.0001(8) \\
-0.0575(4) \pm 0.0001(7) \\
3.70 \AA^{3}\end{array}$ & $\begin{array}{l}0.50000 \\
0.0153(0) \pm 0.0002(2) \\
-0.0536(3) \pm 0.0001(8) \\
5.03 \AA^{2}\end{array}$ \\
\hline
\end{tabular}

Acta Chem. Scand. 14 (1960) No. 7 


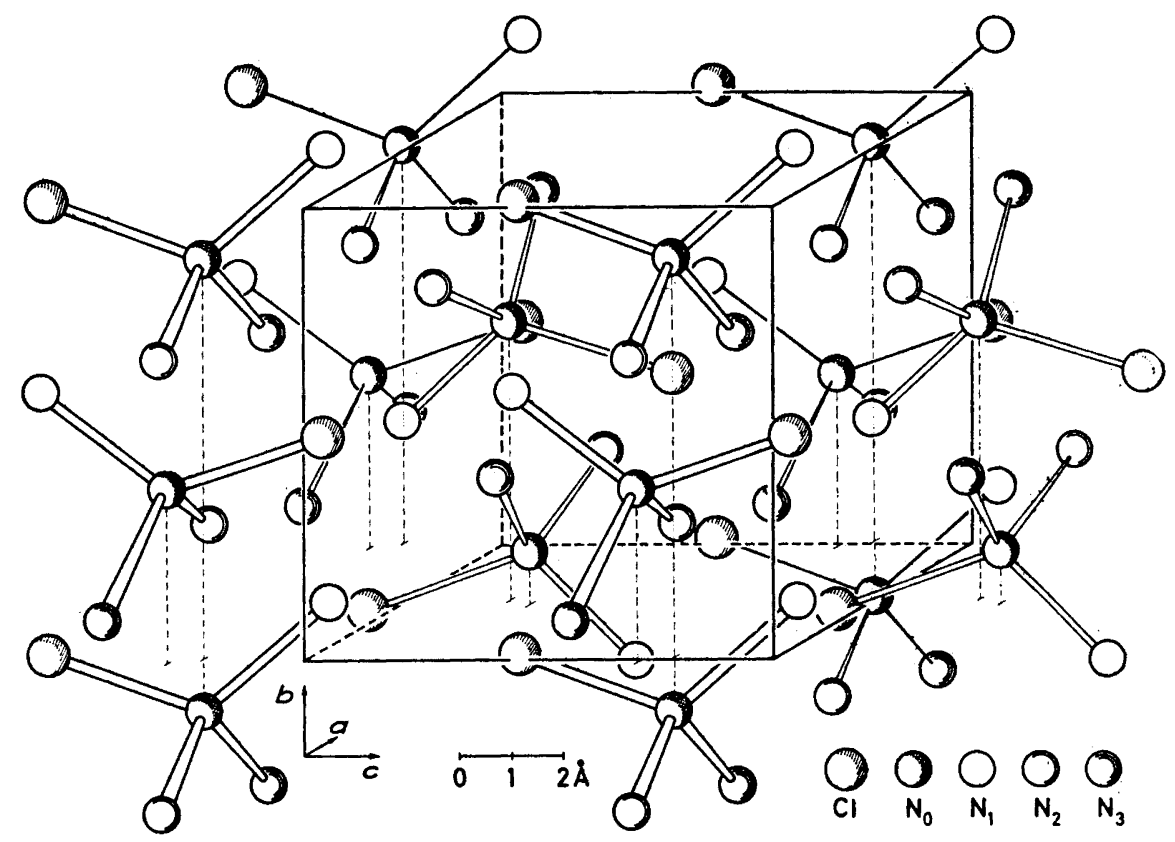

Fig. 2. The crystal structure of $\mathrm{NH}_{4} \mathrm{Cl} \cdot 3 \mathrm{NH}_{3} . \mathrm{N}_{0}$ is nitrogen in the ammonium ion; $N_{1}, N_{2}$ and $N_{3}$ belong to the three ammonia molecules. The hydrogen bonds within the discrete chlorotriammineammonium tetrahedra are indicated.

nate since the iodine atom determines the origin.) The "unreliability factors" at this point were:

For the chloride: $R_{1}=\Sigma|| F_{o}|-| F_{c}|| / \Sigma\left|F_{0}\right|=0.117$

$$
\begin{aligned}
& R_{2}=\left[\Sigma\left(\left|F_{o}\right|-\left|F_{c}\right|\right)^{2} / \Sigma\left|F_{o}\right|^{2}\right]^{3 / 2}=0.118 \\
& R_{3}=\left[\left.\Sigma w\left(\left|F_{o}\right|-\left|F_{c}\right|\right)^{2}|\Sigma w| F_{o}\right|^{2}\right]^{1 / 2}=0.120
\end{aligned}
$$

For the bromide $R_{1}=0.115, R_{2}=0.138, R_{3}=0.142$

For the iodide: $R_{1}=0.101, R_{2}=0.121, R_{3}=0.138$

The number of reflections recorded (not counting the space group extinctions) was $\mathbf{7 4 3}$ for the chloride, 758 for the bromide and 584 for the iodide *.

\section{DISCUSSION OF THE STRUCTURE}

The structure of the chloride and bromide compounds is illustrated in Figs. 2 and 3 (the pictures are based on the parameters of the chloride). The structure of the iodide is shown in Fig. 4. Apart from some shifts in the atomic positions, the main difference between the two structures is that $\mathrm{N}_{2}$ and $\mathrm{N}_{3}$ are interchanged in certain cases. In other words, $\mathrm{N}_{2}$ and $\mathrm{N}_{3}$ taken together occupy

* Copies of the lists of observed and calculated structure factors may be obtained on request from the Institute of Chemistry, University of Uppsala, Uppsala, Sweden. 


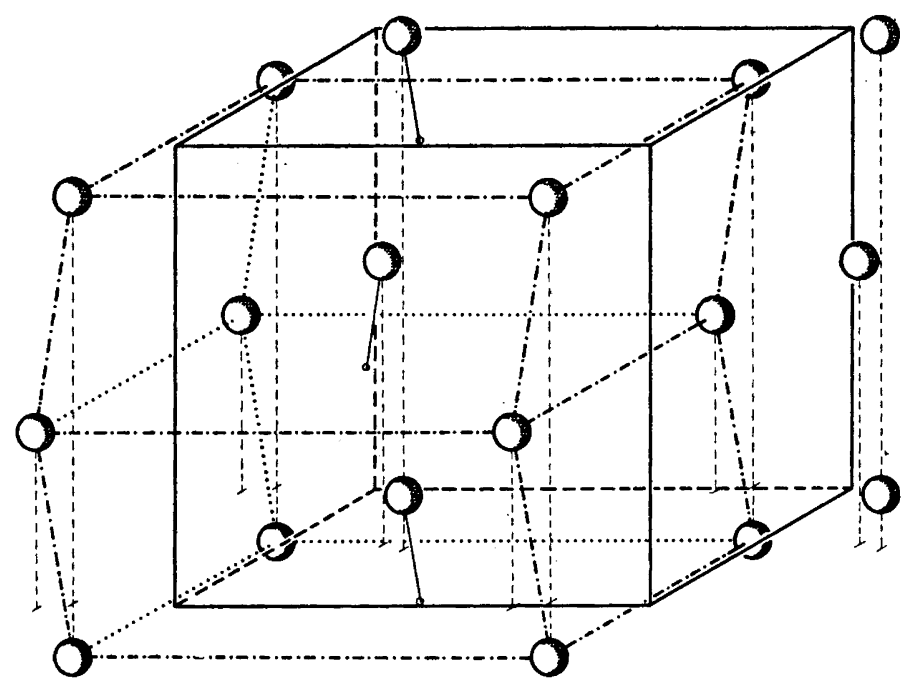

Fig. 3. The arrangement of the central atoms $\left(\mathrm{N}_{0}\right)$ in the tetrahedra of Fig. $2\left(\mathrm{NH}_{6} \mathrm{Cl} \cdot 3 \mathrm{NH}_{3}\right)$. These centers, as indicated by the dotted lines, approximate a body-centered lattice.

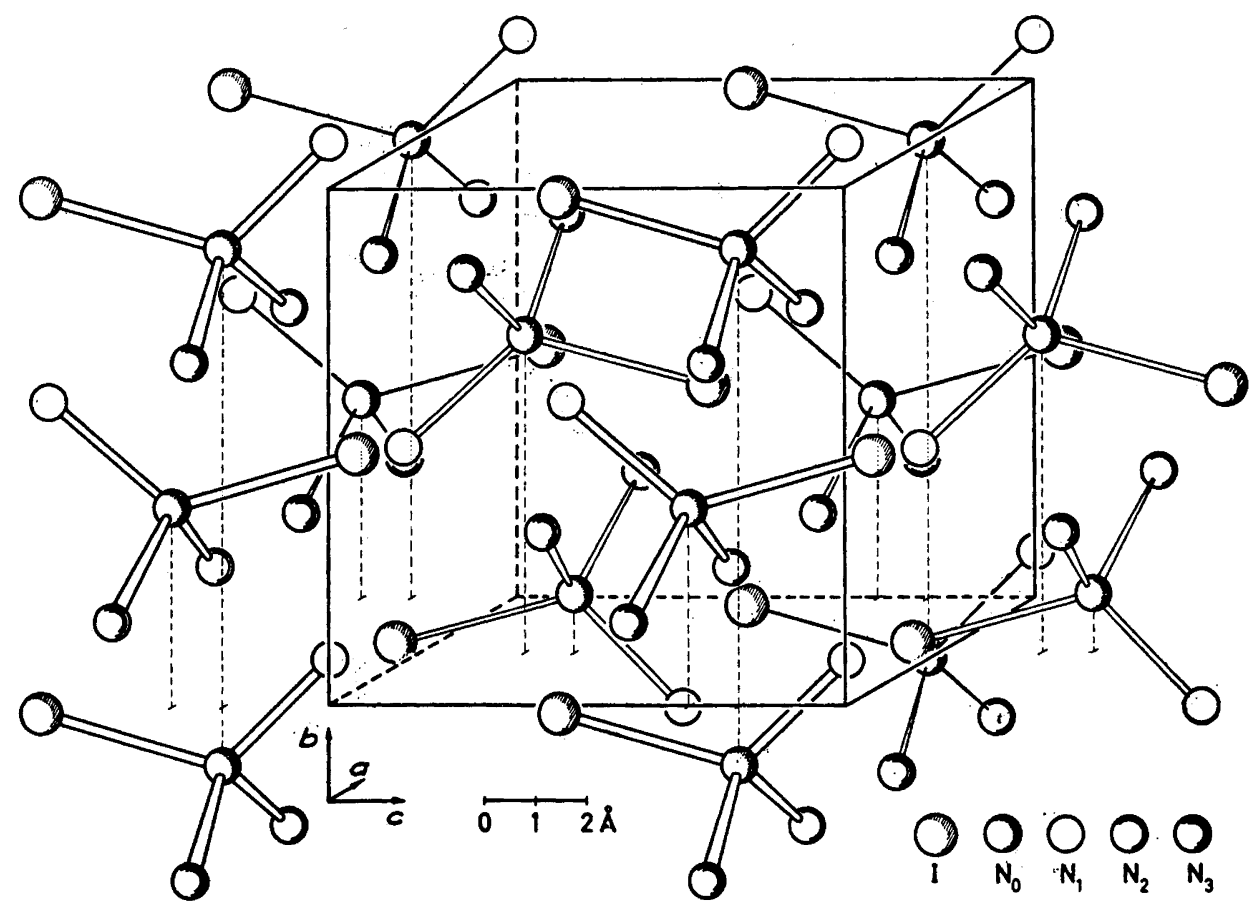

Fig. 4. The crystal structure of $\mathrm{NH}_{4} \mathrm{I} \cdot 3 \mathrm{NH}_{3}$; cf. Fig. 2.

Acta Chem. Scand. 14 (1960) No. 7 
nearly the same positions in the two structures, which is plainly noticeable when all equivalent positions are written down.

It appears that one of the four non-equivalent nitrogen atoms $\left(\mathrm{N}_{0}\right)$ is tetrahedrally surrounded by one halogen and three other nitrogen atoms $\left(\mathrm{N}_{1}\right.$, $\mathrm{N}_{2}$ and $\mathrm{N}_{3}$ ). These three nitrogen atoms have very similar environments, completely different from that of $\mathrm{N}_{0}$. These facts give rather definite indication that $\mathrm{N}_{0}$ belongs to the ammonium ion and $\mathrm{N}_{1}, \mathrm{~N}_{2}$ and $\mathrm{N}_{3}$ to the ammonia molecules. A detailed discussion of the bonding situation is given below.

\section{A m monium}

The bond distances and angles to the four nearest neighbors of ammonium are shown in Figs. 5 and 6 for the chloride compound. The distances and angles, together with their standard deviations for all three compounds, are given in Table 2. The hydrogen atoms of ammonium are obviously used to form hydrogen bonds to the four neighbors. The somewhat distorted tetrahedral arrangement suggests that the hydrogen atoms may be somewhat removed from the bond axes. The difference synthesis for the chloride, shown schematically in Fig. 7, supports this suggestion and also indicates an expected anisotropy of thermal vibration. The distances $\mathrm{N}-\mathrm{N}$ are within the usual range for hydrogen bonds of this kind ${ }^{12}$, except for the short distance $\mathrm{N}_{0}-\mathrm{N}_{3}$ in the iodide, $2.66 \AA$. Compare the distances $\mathrm{N}_{0}-\mathrm{X}$ with the corresponding distances in the simple ammonium halides: $\mathrm{NH}_{4} \mathrm{Cl}$ (CsCl-type, $3.35 \AA$; NaCl-type $\left.\left(250^{\circ} \mathrm{C}\right), 3.26 \AA\right), \mathrm{NH}_{4} \mathrm{Br}\left(3.50\right.$ and $\left(250^{\circ} \mathrm{C}\right) 3.45 \AA$, resp. $), \mathrm{NH}_{4} \mathrm{I}\left(3.79\left(-17^{\circ} \mathrm{C}\right)\right.$ and $3.62 \AA$, resp.). Compare also with other $\mathrm{N}-\mathrm{H}-\mathrm{X}$ distances collected in Ref. ${ }^{12}$

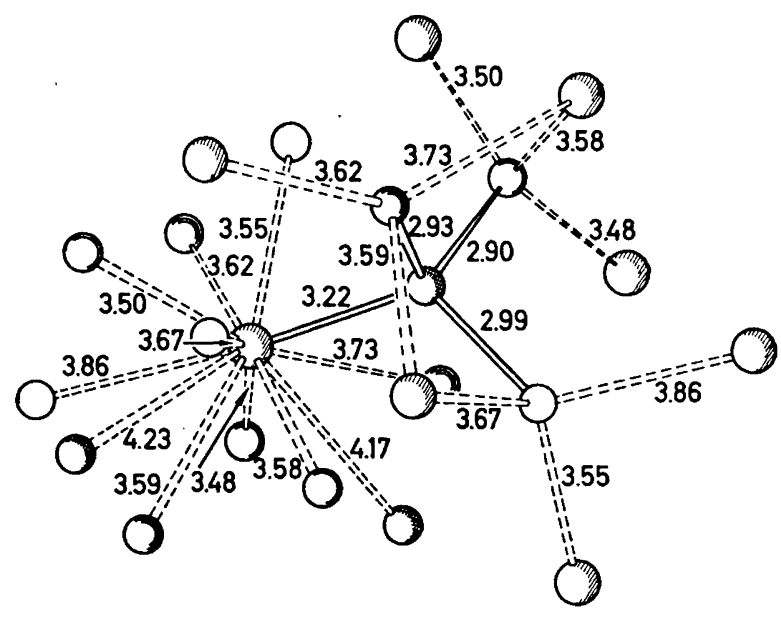

Fig. 5. Bond distances to the neighbors of the different atoms in $\mathrm{NH}_{4} \mathrm{Cl} \cdot 3 \mathrm{NH}_{3}$. The central atom $\mathrm{N}_{0}$ is at $(0.48,0.12,0.28)$ in Fig. 2. Atoms are designated as in Fig. 2. 


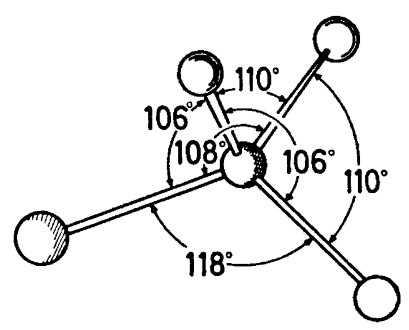

Fig. 6. Bond angles within the tetrahedral groups of Fig. $2\left(\mathrm{NH}_{4} \mathrm{CI} \cdot 3 \mathrm{NH}_{3}\right)$. The corresponding distances are shown in Fig. 5.

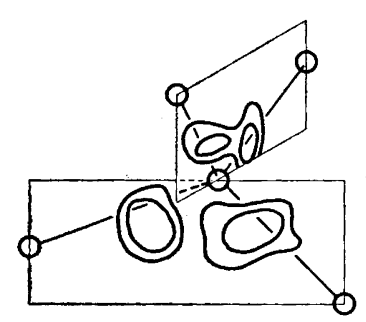

Fig. 7. Schematic representation of the difference synthesis in various sections $\left(\mathrm{NH}_{4} \mathrm{Cl} \cdot 3 \mathrm{NH}_{3}\right)$. The atoms are the same as in Fig. 6. The contours are drawn at 0.4 and 0.5 e. $\AA^{-3}$.

\section{A m monia}

From the discussion above, it follows that the free electron pairs of the ammonia molecules are involved in hydrogen bonds to the central ammonium ion. Bonding between the ammonia molecules themselves then seems improbable and the large interatomic distances support this (all such distances are larger than $3.5 \AA$ ). The other kind of neigh bors to be considered are the halogen atoms. Each ammonia molecule forms, together with the three closest halogen neighbors, a fairly symmetric low pyramid; the distances and angles for the chloride are shown in Figs. 5 and 8 and for all three compounds in Table 3. The average distances are: $\mathrm{N}-\mathrm{Cl}=3.59 \AA, \mathrm{N}-\mathrm{Br}=3.72 \AA$, $\mathrm{N}-\mathrm{I}=3.86 \AA$ (the distances $\mathrm{N}_{1}-\mathrm{Cl}=3.86 \AA, \mathrm{N}_{1} \longrightarrow \mathrm{Br}=4.01 \AA$ and $\mathrm{N}_{1} \longrightarrow \mathrm{I}=4.41 \AA$ are not included in these average values, as they deviate significantly from the rest). The distances to other halogen neighbors are larger than $5 \AA$.

Table 2. Bond distances and angles with their standard deviations around the ammonium ion (cf. Figs. 5 and 6 )

$\begin{array}{lc}\text { Distance } & \mathrm{NH}_{4} \mathrm{Cl} \cdot 3 \mathrm{NH}_{3} \\ \mathrm{~N}_{0}-\mathrm{N}_{1} & 2.99(3) \pm 0.01(4) \AA \\ \mathrm{N}_{0}-\mathrm{N}_{2} & 2.89(6) \pm 0.01(5) \\ \mathrm{N}_{0}-\mathrm{N}_{3} & 2.93(2) \pm 0.01(5) \\ \mathrm{N}_{0}-\mathrm{X} & 3.22(1) \pm 0.01(0) \\ \mathrm{N}_{0} \text {-others } & >3.6 \AA\end{array}$

$\mathrm{NH}_{4} \mathrm{Br} \cdot 3 \mathrm{NH}_{3}$
$2.95(2) \pm 0.02(3) \AA$
$2.81(7) \pm 0.02(6)$
$2.91(5) \pm 0.02(5)$
$3.39(1) \pm 0.01(5)$
$>3.7 \AA$

$110.7 \pm 0.7^{\circ}$

$106.3 \pm 0.7$

$117.9 \pm 0.6$

$111.0 \pm 0.7$

$106.6 \pm 0.6$

$104.1 \pm 0.6$

$$
\begin{aligned}
& \mathrm{NH}_{4} \mathrm{I} \cdot 3 \mathrm{NH}_{3} \\
& 3.05(8) \pm 0.04(9) \AA \\
& 2.98(5) \pm 0.07(0) \\
& 2.65(5) \pm 0.06(2) \\
& 3.64(1) \pm 0.02(3)
\end{aligned}
$$

$$
\begin{aligned}
& 109.5 \pm 0.4^{\circ} \\
& 105.8 \pm 0.4 \\
& 118.2 \pm 0.4 \\
& 110.0 \pm 0.4 \\
& 107.6 \pm 0.4 \\
& 105.5 \pm 0.4
\end{aligned}
$$

$115.5 \pm 1.8^{\circ}$

$106.5 \pm 1.9$

$120.9 \pm 1.1$

$103.8 \pm 1.5$

$102.2 \pm 1.4$

$106.5 \pm 1.4$ 


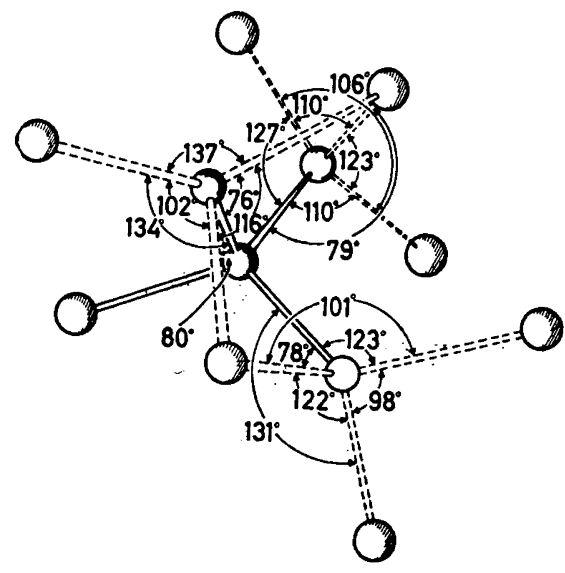

Fig. 8. Angles between the $\mathrm{N}-\mathrm{N}_{0}$ and $\mathrm{N}-\mathrm{Cl}$ lines of each ammonia molecule. The corresponding distances are shown in Fig. 5.

The interaction of the ammonia molecules with their neighbors is obviously weak and makes it probable that the threefold axis is oriented along the hydrogen bond to the central ammonium ion. An interesting question is then the extent of rotation around the threefold axis. The favorable arrangement of three negatively charged halogen atoms suggests that the hydrogen atoms are preferably oriented towards these atoms; the three-dimensional difference synthesis of the chloride seems to give rather definite support to this suggestion. Two typical sections are illustrated in Fig. 9; the corresponding sections involving the other ammonia molecules are very similar. As expected (if the threefold axis is oriented along $\mathrm{N}_{0}-\mathrm{N}_{2}$ ), the "hydrogen atom" appearing in the plane of $\mathrm{N}_{0}, \mathrm{~N}_{2}$ and $\mathrm{Cl}^{\prime}$ is quite far off the connecting line $\mathrm{N}_{2}-\mathrm{Cl}^{\prime}$ which gives more reasonable bond angles in the ammonia molecule (the angle $\mathrm{N}_{0}-\mathrm{N}_{2}-\mathrm{Cl}^{\prime}$ is $79^{\circ}$, see Fig. 8). It seems likely that a phase transition
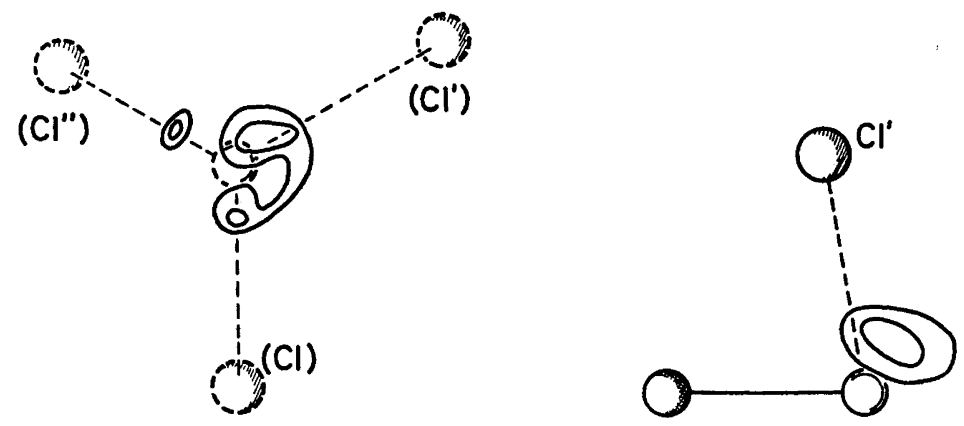

Fig. 9. Difference synthesis in two different sections. In the right picture the section passes through $\mathrm{N}_{0}, \mathrm{~N}_{2}$ and $\mathrm{Cl}^{\prime}$; in the left it is drawn approximately perpendicular to the $\mathrm{N}_{0}-\mathrm{N}_{2}$ bond axis and through those places expected for the hydrogen atoms of $\mathrm{N}_{\mathbf{2}}$, as discussed in the text. The contours are drawn at 0.4 and 0.5 e. $\AA^{-3}$. 
Table 3. Distances and angles to the neighbors of the ammonia molecules (cf. Figs. 5 and 8)

\begin{tabular}{|c|c|c|c|}
\hline Distance & $\mathrm{NH}_{4} \mathrm{Cl} \cdot 3 \mathrm{NH}_{3}$ & $\mathrm{NH}_{4} \mathrm{Br} \cdot 3 \mathrm{NH}_{3}$ & $\mathrm{NH}_{4} \mathrm{I} \cdot 3 \mathrm{NH}_{2}$ \\
\hline $\begin{array}{l}N_{1}-N_{0} \\
N_{1}-X^{\prime} \\
N_{1}-X^{\prime} \\
N_{1}-X^{\prime \prime} \\
N_{1} \text {-other } N\end{array}$ & $\begin{array}{c}2.99(3) \AA \\
3.86(1) \\
3.66(9) \\
3.55(2) \\
>3.6 \AA\end{array}$ & $\begin{array}{c}2.95(2) \AA \\
4.00(5) \\
3.80(7) \\
3.72(6) \\
>3.7 \AA\end{array}$ & $\begin{array}{c}3.05(8) \AA \\
4.41(2) \\
3.88(6) \\
3.88(1) \\
>3.7 \AA\end{array}$ \\
\hline $\begin{array}{l}\mathrm{N}_{2}-\mathrm{N}_{0} \\
\mathrm{~N}_{2}-\mathrm{X}^{\prime} \\
\mathrm{N}_{2}-\mathrm{X}^{\prime} \\
\mathrm{N}_{2}-\mathrm{X}^{\prime \prime} \\
\mathrm{N}_{2} \text {-other N }\end{array}$ & $\begin{array}{r}2.89(6) \\
3.48(4) \\
3.57(9) \\
3.50(3) \\
>3.5 \AA\end{array}$ & $\begin{array}{r}2.81(7) \\
3.61(5) \\
3.67(6) \\
3.67(3) \\
>3.5 \AA\end{array}$ & $\begin{array}{r}2.98(5) \\
3.75(6) \\
3.95(6) \\
3.78(0) \\
>3.6 \AA\end{array}$ \\
\hline $\begin{array}{l}\mathbf{N}_{3}-N_{0} \\
N_{3}-X^{\prime} \\
\mathbf{N}_{3}-X^{\prime} \\
N_{3}-X^{\prime \prime} \\
N_{3} \text {-other } N\end{array}$ & $\begin{array}{r}2.93(2) \\
3.59(4) \\
3.73(3) \\
3.61(9) \\
>3.5 \AA\end{array}$ & $\begin{array}{c}2.91(5) \\
3.68(8) \\
3.80(3) \\
3.75(3) \\
>3.5 \AA\end{array}$ & $\begin{array}{c}2.65(5) \\
3.79(9) \\
3.87(4) \\
3.91(0) \\
>3.6 \AA\end{array}$ \\
\hline Angle & $\mathrm{NH}_{4} \mathrm{Cl} \cdot 3 \mathrm{NH}_{3}$ & $\mathrm{NH}_{4} \mathrm{Br} \cdot 3 \mathrm{NH}_{3}$ & $\mathrm{NH}_{4} \mathrm{I} \cdot 3 \mathrm{NH}_{3}$ \\
\hline $\begin{array}{l}N_{0}-N_{1}-X \\
N_{0}-N_{1}-X^{\prime} \\
N_{0}-N_{1}-X^{\prime \prime} \\
X-N_{1}-X^{\prime} \\
X-N_{1}-X^{\prime \prime} \\
X^{\prime}-N_{1}-X^{\prime \prime}\end{array}$ & $\begin{array}{r}123.3^{\circ} \\
78.1 \\
131.3 \\
100.6 \\
97.9 \\
121.9\end{array}$ & $\begin{array}{r}123.9^{\circ} \\
79.9 \\
133.3 \\
100.3 \\
96.7 \\
117.6\end{array}$ & $\begin{array}{r}120.8^{\circ} \\
79.9 \\
136.7 \\
102.9 \\
98.9 \\
109.2\end{array}$ \\
\hline $\begin{array}{l}\mathrm{N}_{0}-\mathrm{N}_{2}-\mathrm{X}^{\prime} \\
\mathrm{N}_{0}-\mathrm{N}_{2}-\mathrm{X}^{\prime} \\
\mathrm{N}_{0}-\mathrm{N}_{2}-\mathrm{X}^{\prime \prime} \\
\mathrm{X}-\mathrm{N}_{2}-\mathrm{X}^{\prime} \\
\mathrm{X}-\mathrm{N}_{2}-\mathrm{X}^{\prime \prime} \\
\mathrm{X}^{\prime}-\mathrm{N}_{2}-\mathrm{X}^{\prime \prime}\end{array}$ & $\begin{array}{r}110.3 \\
79.3 \\
127.2 \\
123.4 \\
106.4 \\
109.8\end{array}$ & $\begin{array}{r}109.3 \\
80.5 \\
129.5 \\
123.8 \\
104.9 \\
109.4\end{array}$ & $\begin{array}{r}87.3 \\
84.5 \\
129.6 \\
123.4 \\
113.8 \\
114.2\end{array}$ \\
\hline $\begin{array}{l}\mathrm{N}_{0}-\mathrm{N}_{3}-\mathrm{X} \\
\mathrm{N}_{0}-\mathrm{N}_{3}-\mathrm{X}^{\prime} \\
\mathrm{N}_{0}-\mathrm{N}_{3}-\mathrm{X}^{\prime \prime} \\
\mathrm{X}-\mathrm{N}_{3}-\mathrm{X}^{\prime} \\
\mathrm{X}-\mathrm{N}_{3}-\mathrm{X}^{\prime \prime} \\
\mathrm{X}^{\prime}-\mathrm{N}_{3}-\mathrm{X}^{\prime \prime}\end{array}$ & $\begin{array}{r}80.1 \\
76.3 \\
133.7 \\
116.1 \\
101.7 \\
136.5\end{array}$ & $\begin{array}{r}82.5 \\
77.2 \\
135.1 \\
118.3 \\
101.9 \\
132.8\end{array}$ & $\begin{array}{r}86.6 \\
90.6 \\
130.8 \\
124.5 \\
109.9 \\
113.1\end{array}$ \\
\hline
\end{tabular}

should be expected if relatively unrestricted rotation around the threefold axis occurred at higher temperatures. As pointed out earlier, no phase transitions were observed in the $\mathrm{X}$-ray photographs as the crystals were cooled down from the melting point to $-140^{\circ} \mathrm{C}$. So far no heat capacity measurements have been published.

\section{3. $\mathrm{H}$ a $\mathrm{log}$ e $\mathrm{n}$}

The closest neighbors to a halogen atom are three nitrogen atoms of each kind. The distances for the chloride are shown in Fig. 5 and for all three compounds in Table 4. Of the three ammonium neighbors, only one points a 
Table 4. Distances to the neighbors of the halogen atoms (cf. Fig. 5).

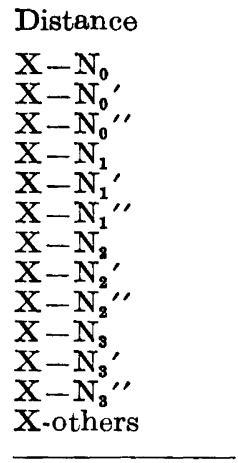

* Also: 4.50(5).

** Also: 4.71(9).

$\mathrm{NH}_{4} \mathrm{Cl} \cdot 3 \mathrm{NH}_{3}$
$3.22(\mathrm{I}) \AA$
$4.23(2)$
$4.16(5)$
$3.86(1)$
$3.66(9)$
$3.55(2)$
$3.48(4)$
$3.57(9)$
$3.50(3)$
$3.59(4)$
$3.73(3)$
$3.61(9)$
$>4.9 \AA$

$\mathrm{NH}_{4} \mathrm{I} \cdot 3 \mathrm{NH}_{3}$

$3.64(1) \AA$

$4.68(7)$

4.72(1)*

$4.41(2) * *$

$3.88(6)$

$3.88(1)$

$3.79(9)\left(\mathrm{I}-\mathrm{N}_{\mathrm{s}}\right)$

$3.87(4)\left(\mathrm{I}-\mathrm{N}_{3}{ }^{\prime}\right)$

$3.78(0)$

$3.75(6)\left(\mathrm{I}-\mathrm{N}_{2}\right)$

$3.95(6)\left(\mathrm{I}-\mathrm{N}_{2}^{\prime}\right)$

$3.91(0)$

hydrogen atom towards this halogen atom as the other two are directly involved in bonds to other halogen atoms. These two ammonium ions are also considerably more distant. If now the hydrogen atoms of the ammonia molecules are also preferably oriented towards halogen as discussed above, this means that altogether ten hydrogen atoms are more or less directed towards halogen. The preceding discussion has to be modified somewhat in the iodide case. From Table 4 it is apparent that the distances $\mathrm{I}-\mathrm{N}_{0}{ }^{\prime}, \mathrm{I}-\mathrm{N}_{0}{ }^{\prime \prime}$ and $\mathrm{I}-\mathrm{N}_{1}$ are considerably larger than the corresponding distances in the chloride and bromide structure. It is then not too surprising that two extra atoms, other than these twelve, are also situated at comparable distances (see the foot-note in the table). As was pointed out earlier, $\mathrm{N}_{2}$ and $\mathrm{N}_{3}$ are interchanged in certain cases when the iodide structure is compared to the chloride and bromide structure, which is also shown in this table.

It may be worth mentioning that the halogen atoms form an approximately face-centered arrangement. If the halogen coordinates were $\left(\frac{1}{2}, 0,0\right)$ instead of those given in Table 1, the face-centering would be perfect.

As a summary, the structures are characterized by rather discrete halidotriammineammonium tetrahedra (Figs. 2 and 4). The forces between these groups are relatively weak; the tetrahedra are arranged in such a way that their centers form a flat (close to) body-centered lattice (Fig. 3). The possible rotation of the ammonia molecules about their threefold axes may be relatively restricted by interaction with the halide neighbors. It must be pointed out that the individuality of the tetrahedral groups is much less pronounced in the iodide than in the other two. Note, for example, that the distance $\mathrm{N}_{0}-\mathrm{I}$ within the group is $3.64 \AA$, while the distance from $\mathrm{N}_{2}$ to one of the iodine atoms in a neighboring group is not much longer, $3.76 \AA$.

Acknowledgements. The preliminary work on the bromide and iodide compounds was done in collaboration with Mr Gunnar Larsson and Mr Rune Liminga and I am much indebted to them for their very valuable assistance. 
Sincere thanks are due to Professor G. Hägg for his great interest in this work and for all the facilities put at my disposal. The refinements were performed on the IBM 650 and 701 computers during my stay at the Lawrence Radiation Laboratory of the University of California, Berkeley, U.S.A., with support of the U.S. Atomic Energy Commission, and I am much indebted to Professor D. H. Templeton for permission to use these facilities.

This work has been supported by several grants from the Swedish Natural Science Research Council which are here gratefully acknowledged.

\section{REFERENCES}

1. Watt, G. W. and McBride, W. R. J. Am. Chem. Soc. 77 (1955) 1317.

2. Olovsson, I. Acta Chem. Scand. 11 (1957) 1273.

3. Kreuger, A. Acta Cryst. 8 (1955) 348.

4. Olovsson, I. and Templeton, D. H. Acta Cryst. 12 (1959) 827.

5. Weisz, O., Cochran, W. and Cole, W. F. Acta Cryst 1 (1948) 83.

6. Löfgren, T. Acta Cryst. (1960) In press.

7. International Tables for X-ray Crystallography, Vol 1, Kynoch Press, Birmingham 1952.

8. Hägg, G., and Laurent, T. J. Sci. Instr. 23 (1946) 155.

9. Templeton, D. H. Z. Krist. 113 (1960) 234.

10. Berghuis, J., Haanappel, IJ. M., Potters, M., Loopstra, B. O., MacGillavry, C. H. and Veenendaal, A. L. Acta Cryst. 8 (1955) 478.

11. Thomas, L. H. and Umeda, K. J. Chem. Phys. 26 (1957) 293.

12. Pimentel, G. C., and McClellan, A. L. The Hydrogen Bond, Freeman and Co., San Francisco and London 1960.

Received July 1, 1960. 